\title{
MEMORANDUM
}

No 07/2015

\section{The Economics of Trafficking for Sexual Exploitation}

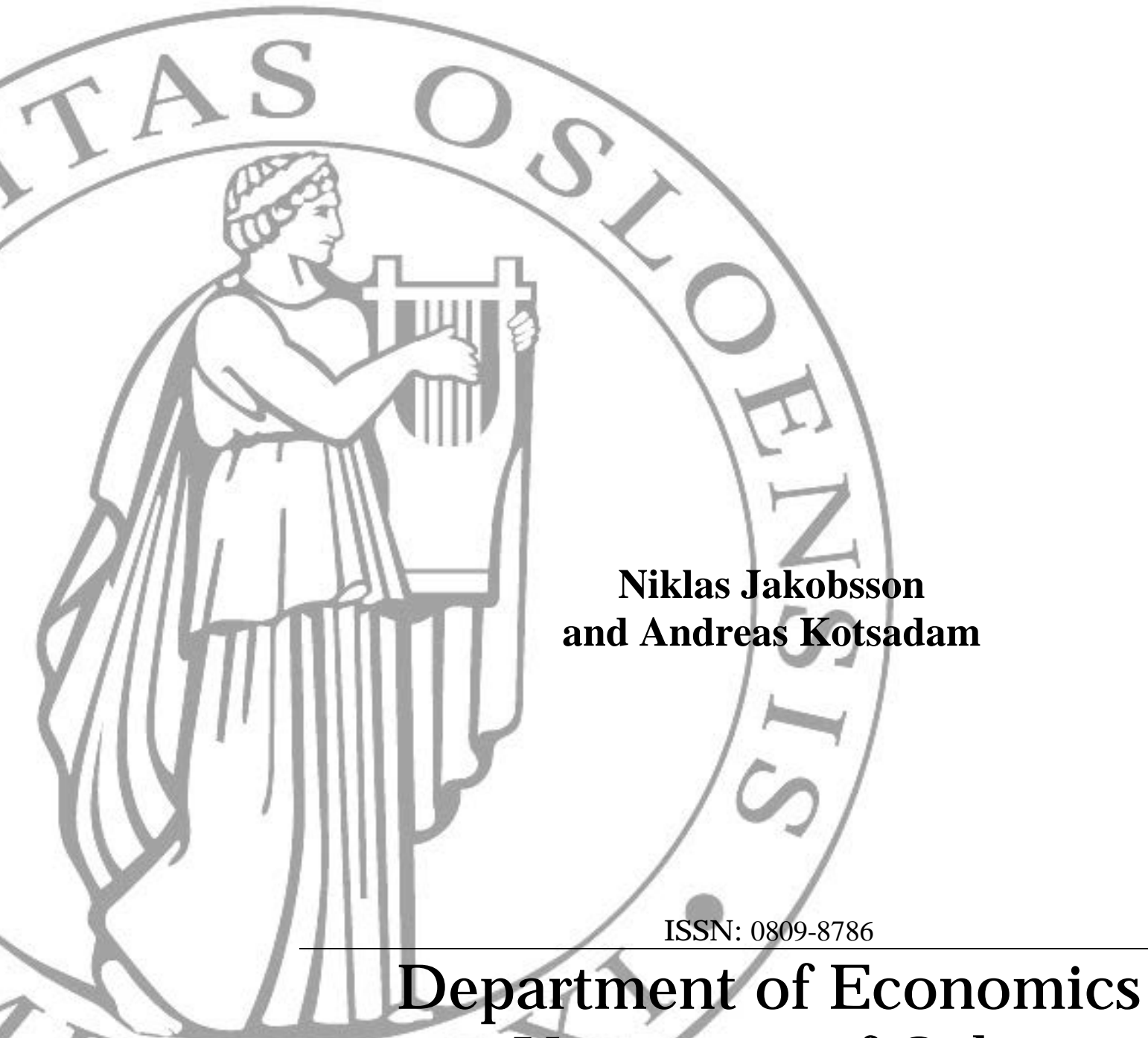

University of $\mathrm{O}$ slo 
This series is published by the

\section{University of Oslo Department of Economics}

P. O.Box 1095 Blindern

N-0317 OSLO Norway

Telephone: + 4722855127

Fax: $\quad+4722855035$

Internet: http://www.sv.uio.no/econ

e-mail: $\quad$ econdep@econ.uio.no
In co-operation with

The Frisch Centre for Economic

Research

Gaustadalleén 21

N-0371 OSLO Norway

Telephone: $\quad$ +4722958820

Fax: $\quad+4722958825$

Internet: $\quad$ http://www.frisch.uio.no

e-mail: $\quad$ frisch@frisch.uio.no

\section{Last 10 Memoranda}

\begin{tabular}{|c|c|}
\hline No $06 / 15$ & $\begin{array}{l}\text { Geir B. Asheim and Stéphane Zuber } \\
\text { Evaluating Intergenerational Risks: Probability Adjusted Rank-Discounted } \\
\text { Utilitarianism }\end{array}$ \\
\hline No $05 / 15$ & $\begin{array}{l}\text { Fridrik Mar Baldursson and Nils-Henrik von der Fehr } \\
\text { Natural Resources and Sovereign Expropriation }\end{array}$ \\
\hline No $04 / 15$ & $\begin{array}{l}\text { Erik Biørn and Xuehui Han } \\
\text { Persistence, Signal-Noise Pattern and Heterogeneity in Panel Data: With } \\
\text { an Application to the Impact of Foreign Direct Investment in GDP }\end{array}$ \\
\hline No $03 / 15$ & $\begin{array}{l}\text { Alice Ciccone } \\
\text { Environmental Effects of a Vehicle Tax Reform: Empirical Evidence from } \\
\text { Norway }\end{array}$ \\
\hline No $02 / 15$ & $\begin{array}{l}\text { Katinka Holtsmark and Kristoffer Midttømme } \\
\text { The Dynamics of Linking Permit Markets }\end{array}$ \\
\hline No $01 / 15$ & $\begin{array}{l}\text { Francesco Lania and Alessia Russo } \\
\text { Public Education and Pensions in Democracy: A Political Economy } \\
\text { Theory }\end{array}$ \\
\hline No $29 / 14$ & $\begin{array}{l}\text { Lars Kirkebøen, Edwin Leuven and Magne Mogstad } \\
\text { Field of Study, Earnings, and Self-Selection }\end{array}$ \\
\hline No $28 / 14$ & $\begin{array}{l}\text { Erik Biørn } \\
\text { Serially Correlated Measurement Errors in Time Series Regression: The } \\
\text { Potential of Instrumental Variable Estimators }\end{array}$ \\
\hline No $27 / 14$ & $\begin{array}{l}\text { Erik Biørn } \\
\text { The Price-Quantity Decomposition of Capital Values Revisited: } \\
\text { Framework and Examples }\end{array}$ \\
\hline No $26 / 14$ & $\begin{array}{l}\text { Olav Bjerkholt } \\
\text { Econometric Society 1930: How it Got Founded }\end{array}$ \\
\hline
\end{tabular}

Previous issues of the memo-series are available in a PDF® format at: http://www.sv.uio.no/econ/english/research/unpublished-works/working-papers/ 


\title{
The Economics of Trafficking for Sexual
}

\author{
Exploitation*
}

\author{
Niklas Jakobsson ${ }^{\dagger}$ and Andreas Kotsadam ${ }^{\ddagger}$ \\ Memo 07/2015-v1 \\ (This version March 11, 2015)
}

\begin{abstract}
International human trafficking of women for commercial sexual exploitation (henceforth trafficking) is an economic activity in which organizations try to make profits. Trafficking has been identified as a form of modern-day slavery and is a worldwide problem which has grown rapidly in the last decades. Despite this, the economics literature on trafficking is small, which is somewhat surprising given that the economics of immigration as well as the economics of crime are both large areas of research. We review the existing economics literature on trafficking with a particular focus on the gaps in this literature. We also describe the datasets that have been and can be used in studying trafficking and we point to future areas of research. We believe that economists have a lot to contribute to the knowledge of the determinants of trafficking and, as more and improved data becomes readily available, the possibilities for credible quantitative research in this area will grow.
\end{abstract}

Keywords: Law and economics; Prostitution; Sexual exploitation; Sex slavery; Trafficking

JEL classification: F22; F60; J16; K14; O15

\footnotetext{
*The paper is forthcoming as a chapter in the Handbook on the Economics of Prostitution, Oxford University Press. We would like to thank Seo-Young Cho, Samuel Lee, Toman Omar Mahmoud, Petra Persson, Christina Presenti, Cristoph Trebesch and Elisabeth Wheaton for useful comments. The project is part of the research activities at the Centre for the Study of Equality, Social Organization, and Performance (ESOP) at the Department of Economics, University of Oslo. ESOP is supported by the Research Council of Norway.

${ }^{\dagger}$ Norwegian Social Research and Karlstad University, nja@nova.no

$\ddagger$ University of Oslo, andreas.kotsadam@econ.uio.no
} 


\section{Introduction}

International human trafficking of women for commercial sexual exploitation (henceforth trafficking) has been identified as a form of modern-day slavery and is a worldwide problem which has grown rapidly in the last decades (Bettio and Nandi 2010; Hodge and Leitz 2007). According to the European Commission (2009), trafficking in human beings is a serious crime and gross violation of human rights and efforts to reduce it is highly prioritized in many countries. Governments throughout the world view human trafficking as a component of organized crime and the average punishment for traffickers is comparable to that of other types of serious transnational crimes (Morrison and Crosland 2001). Trafficking is also regarded as a crime against humanity in the Statute of the International Criminal Court (Article 7.2).

It has been difficult to reach a consensus on how to define trafficking and it was not until 2000 that the UN General Assembly adopted a common definition, referred to as the Palermo Protocol, which defines trafficking as: "Trafficking in persons' shall mean the recruitment, transportation, transfer, harboring or receipt of persons, by means of the threat or use of force or other forms of coercion, of abduction, of fraud, of deception, of the abuse of power or of a position of vulnerability or of the giving or receiving of payments or benefits to achieve the consent of a person having control over another person, for the purpose of exploitation."

In the present chapter we review the economics literature on trafficking, describe the datasets that have been and can be used in studying trafficking, and point to future areas of research. The economics literature on trafficking is small, which is somewhat surprising given that the economics of immigration as well as the economics of crime are both large areas of research. One likely reason for this is, we argue, the limited amount of reliable and detailed data on trafficking. Nonetheless, it is our firm belief that economists have a lot to contribute to knowledge of the determinants of trafficking and, as more and improved data becomes readily available, the possibilities for credible quantitative research in this area will grow.

A starting point from which to consider the choices made by agents in the market for trafficking is the identification of those agents' intentions. Trafficking is an economic activity in which organizations try to make profits (Salt 2000; Salt and Stein 1997). Traffickers will only sell persons for sexual exploitation when market conditions make it profitable (UNODC 2009). Evidence suggests 
that human traffickers belong to organized criminal organizations and that they act as businessmen trying to maximize profits (e.g. Anderson and O'Connell Davidson 2002; Hodge and Leitz 2007; Salt 2000; UNODC 2006; UNODC 2009). Therefore a rational choice perspective on trafficking seems plausible and may yield important insights.

The present chapter is organized around the three main themes that economists have been researching in relation to trafficking. First we will review the research on what determines which type of country people are trafficked to (Section 2). In the next section (Section 3) we will describe the main findings with regard to the determinants of which types of country people are trafficked from. The final review section (Section 4) goes through the few attempts to date to build a coherent picture of the determinants of both destinations and sources of trafficking. The focus of each section is to describe the underlying theories, the available data sets and the main findings of the literature. The final section (Section 5) summarizes the chapter, discusses gaps in the economics trafficking literature and suggests possible areas of future research. A table in the Appendix summarizes information about the data on trafficking that have been used in this research.

\section{What factors determine where people are traf- ficked to?}

The economics studies investigating the determinants of where people are trafficked to have, in recent years, adopted a rational choice framework whereby the profitability of trafficking to a given country hinges on the characteristics of that country's market for commercial sex. The main focus has been on the relationship between prostitution laws and trafficking to a country, but other aspects of migration and market structure have also been considered. The economics papers studying these issues are Di Nicola et al. (2005), DanailovaTrainor and Belser (2006), Jakobsson and Kotsadam (2010; 2013) and Cho et al. (2013).

The starting point is usually an acknowledgement that trafficking for sexual exploitation is an economic activity driven by profit motives and that state action or inaction is decisive for structuring profit possibilities. From this point of departure theoretical predictions have been deduced. Jakobsson and Kotsadam $(2010 ; 2013)$ argue that a crucial factor for the profitability of commercial sex is 
the legal framework surrounding it. Aghatise (2004) argues that it is impossible to combat trafficking where prostitution is sanctioned. This is also the position taken by several governments and it has been an explicit motivation for criminalizing the buying of sex in Norway (Ot.prp. nr.48) and Sweden (Proposition 1997/98: 55) and the US government took a strong position against legalized prostitution using this argument (US Department of State 2004). But as we will see later, theoretically the relationship between prostitution legislation and trafficking inflows is ambiguous. Using the fact that national prostitution legislation differs considerably between countries, several recent articles test the hypothesis that harsher legislation surrounding commercial sex reduces the amount of trafficking to a country (Jakobsson and Kotsadam 2010; 2013; Cho et al. 2012).

The theoretical arguments for why harsher prostitution laws should affect trafficking follow a simple cost and benefit reasoning. Danailova-Trainor and Belser (2006) view trafficking as an exchange between recruiters and exploiters in an illicit market. A recruiter abducts (or recruits) a victim in their country of origin and sells him or her to a brothel owner in a destination country. Jakobsson and Kotsadam (2013) assume vertical integration, with recruiters and brothel owners operating within the same business. Evidence does suggest that human traffickers belong to organized criminal bodies and that they act as businessmen trying to maximize profits (e.g. Salt 2000; UNODC 2006; UNODC 2009). Organized crime has as its major goal the maximization of profits and its success depends on there being exploitable markets (Morrison and Crosland 2001). Thus, the decision made by a trafficker depends on the profit potential. The more profit that can be made in a specific country, the higher is the likelihood that persons will be trafficked to that country. As always, the profit is a function of revenues and costs. The revenues are a function of the price and the quantity sold and should therefore depend positively on the size of the market and the per capita income in the destination country. The costs for the trafficker can be divided into costs for entering a country, such as travel and smuggling costs, and costs for running the business once in the country, such as costly discretion, etc. If the trafficker finds that the benefit exceeds the costs then trafficking to a country will take place.

Important factors for the traffickers' revenues are the purchasing power and the size of the population in countries of destination. Large markets and customers with a high willingness to pay make it more profitable to traffic the women to high-income countries than to low-income countries. Since the deception of migrants is common and since there are fixed costs in establishing 
migration routes, is also argued that increased immigration to a country reduces the costs of trafficking (Jakobsson and Kotsadam 2013). With more immigration to a country, illegal immigration activities may be detected less frequently and the cost of trafficking to that country is lower as routes and networks are already established. However, as argued by Danailova-Trainor and Belser (2006), with more legal migration possibilities trafficking may actually decrease since those wishing to migrate may feel less compelled to deal with human smugglers, who are thought likely to be traffickers. Another important factor determining the costs is the ease or difficulty of setting up and running organized criminal activity in a country. The rule of law and the competence of the police force are two elements that are likely to be important in this respect.

The legal framework surrounding prostitution is crucial since it affects the profit function. It is likely to affect the supply of trafficked women directly by increasing the costs associated with day-to-day aspects of prostitution since street prostitution is not viable. However, an argument can also be made that the composition of the prostitutes changes in such a way that trafficking increases (Cho et al. 2013; see more on this below). Relatedly, the legal structure may affect the costs for traffickers as the principal agency relationship may be altered. For instance, criminalization may increase the monitoring cost of pimps of trafficked prostitutes and as such legalization may imply lower variable costs for voluntary prostitutes who may therefore drive out trafficking from the market. With criminalization, the variable costs may increase relatively more for voluntary prostitutes so that trafficking increases as a result. Laws criminalizing prostitution are likely to affect the demand for prostitution as well, especially if buying sex is illegal. A direct effect would be that people refrain from buying sex since they are afraid of getting caught. There might also be an important indirect effect working through the normative function of the law (Kotsadam and Jakobsson 2011; Jakobsson and Kotsadam 2010, 2013, 2014). Prostitution laws affect the stigmatization of buying and selling sex, which influences the profit function. Della Giusta (2010) and Della Giusta et al. (2008) argue that policies that reduce the stigma associated with supplying sex would increase the marginal net gain of supplying prostitution and the marginal willingness to pay for it would rise. Policies that increase the stigmatization of clients are expected to reduce the marginal willingness to pay, the quantity sold and the equilibrium price. This framework leads Jakobsson and Kotsadam (2013) to expect that slacker prostitution laws lead to more trafficking for sexual exploitation. More specifically, they expect most trafficking to countries where prostitution is legal 
and regulated, least in the countries where buying and/or selling sex is illegal, and flows in-between in countries where it is legal to buy and sell but illegal to profit as a third party (pimps or brothel owners).

Cho et al. (2013) emphasize the important fact that, a priori and theoretically, the effect of prostitution laws on trafficking is uncertain. This is because the legalization of prostitution may have two contradictory effects on the amount of trafficking - a substitution effect away from trafficking and a scale effect increasing trafficking. The scale effect consists of more prostitution once it is legal, and if the share of trafficked victims remains constant the amount of trafficking increases. Kotsadam and Jakobsson argue that the share of trafficking may increase as the opportunity to gain money is increased. However, as Cho et al. (2013) argue, it is a priori equally likely that the composition of the prostitutes may shift towards more national women or non-national women with working permits. As prostitution is legalized it should be easier to recruit local women to the business. We agree that the question is an empirical one and furthermore we argue that the degree of the different effects is likely to be heterogeneous across countries depending on, for example, the degree of available employment for women or the level of prosperity.

A recent theoretical contribution by Lee and Persson (2012) further complements the reasoning around the links between prostitution laws and trafficking. In their framework, criminalizing the sale of sex disadvantages voluntary prostitutes relative to traffickers who do not internalize the criminal penalties borne by their victims. In addition, criminalizing the purchase of sex raises men's valuation of marriage relative to sex, which in equilibrium reduces the supply of voluntary prostitutes since more women opt to marry instead. But it does not affect the supply decision of traffickers who do not internalize the value of alternative life choices they deprive their victims of. Either form of criminalization thus primarily crowds out voluntary prostitutes such that, when voluntary prostitution plays a significant role, they increase the price of commercial sex and hence the profit opportunities for traffickers. However, when voluntary prostitution is insignificant, criminalization does reduce trafficking. Thus, in this setting, neither legalization nor criminalization unambiguously reduces trafficking. Lee and Persson (2012) propose a third option. This is to have regulated prostitution combined with severe punishment for those who purchase unregulated sex.

The available data on trafficking is limited and unsatisfactory in many ways and we strongly encourage efforts to collect better data. To overcome some of 
the problems, Jakobsson and Kotsadam (2013) use two different datasets. In this section we describe the datasets used, as well as their limitations.

Jakobsson and Kotsadam's (2013) first dependent variable (Trafficking) captures the amount of trafficking to a country. It ranges from 1 for countries with a low inflow of trafficking to 5 for countries with a high inflow of trafficking. The data was constructed by the United Nations Office on Drugs and Crime and includes information from 113 institutions providing human trafficking information in 161 countries from 1996 to 2003 (UNDOC 2006). The institutions consist of governments, national criminal justice organizations, international police organizations, non-governmental organizations, research institutes, universities, news agencies, and newspapers. Twenty-four percent of these institutions were international, 26 percent were Western European, 14 percent North American, 13 percent Asian, while the rest came from other parts of the world. One of the main objectives of the database was to gather comparable data (Kangaspunta 2003).

A content analysis of the publications by these institutions was made and 4,950 accounts of trafficking were found. If a country was referred to as a transit, origin or destination country, it was recorded in the database and Jakobsson and Kotsadam (2013) focus solely on destination countries. If one organization referred to the same occasion several times it was only counted once. In order to further minimize the problem of different organizations referring to the same instance of trafficking, efforts were made to refer to the primary source only. It is important to emphasize once again that the dataset counts occasions and not victims, so that a document finding one trafficking victim results in one citation in the database, as does a document that finds 300 victims. The citations for destination countries range between 0 and 40 . If a country got one (1) citation as destination country, it got the score Very low, 2-3 citations was recorded as Low, 4 $\neg-10$ Medium, 11-24 High, and 25-40 Very high. Thirty-nine European countries are included in this dataset. Among these, three countries score Very low, four countries score Low, 16 countries score Medium, 10 countries score High, and six countries score Very high. The countries are listed in the corresponding categories in Table 1 below.

That a broad range of institutions was used as sources improves the data quality. Thirty-two percent of the data comes from international organizations, 27 percent from governmental organizations and 18 percent from research institutions. Despite such a broad range of reporting institutions there are some problems with the data. It only uses sources in English, French, Spanish and 


\begin{tabular}{|c|c|c|c|c|}
\hline Very low & Low & Medium & High & Very high \\
\hline Georgia & Ireland & Albania & Austria & Belgium \\
\hline Moldova & Luxembourg & Bulgaria & Bosnia and Herzegovina & Germany \\
\hline \multirow[t]{14}{*}{ Slovakia } & Romania & Croatia & Cyprus & Greece \\
\hline & Slovenia & Estonia & Czech Republic & Italy \\
\hline & & Finland & Denmark & Netherlands \\
\hline & & Hungary & France & Turkey \\
\hline & & Iceland & Poland & \\
\hline & & Latvia & Spain & \\
\hline & & Lithuania & Switzerland & \\
\hline & & Macedonia & United Kingdom & \\
\hline & & Norway & & \\
\hline & & Portugal & & \\
\hline & & Russia & & \\
\hline & & Serbia and Montenegro & & \\
\hline & & Sweden & & \\
\hline & & Ukraine & & \\
\hline
\end{tabular}

German and 40 percent of the source institutions are in Western Europe or North America, which may create a bias. As argued in UNDOC (2006), the emphasis on Western source organizations may lead to a geographical bias. For this reason the analysis in Jakobsson and Kotsadam (2013) is of European countries. In the European sample it is not necessary to control for laws against trafficking since such laws are in force in all countries except Estonia. Estonia, however, criminalized aspects of trafficking via related offences (UNODC 2009). It can also be argued that law enforcement is quite similar in these countries, so that using the classification of legal regulation is actually meaningful for this sample.

As a complement to the UNDOC data, Jakobsson and Kotsadam (2013) also use a dataset constructed by Danailova-Trainor and Belser (2006) from ILO (International Labour Organization) data. The database is constructed from 2,092 reports containing quantitative information on trafficking 1995-2004. Countrylevel estimates on trafficking victims for sexual exploitation are created by using the average of the available estimates in the ILO database. As Danailova-Trainor and Belser (2006) argue, this data is not ideal since the underlying data may be of bad quality and contain similar problems as pure official statistics on trafficking (which we discuss below). This variable only contains data from 31 European countries so missing data may also be a problem (not confined to Europe, the data includes 74 countries).

Yet another possible dataset to be used in assessing trafficking is official victim data. However, Jakobsson and Kotsadam (2013) argue against the use of this sort of data due to its several problems. The most obvious problem is that countries with plentiful resources and good legal systems may detect a lot of 
trafficking even though the problem of trafficking may not be as severe as in other countries. For criminal data to exist there must be a law, the law enforcement agencies must care enough to act on the problem and be capable of doing so, there must then be a system of data collection and a willingness to provide the data to international organizations. Furthermore, the legal definition of trafficking varies between countries and this may also result in large differences in official records.

The independent variable of main interest in Jakobsson and Kotsadam (2013) is Law, which measures the degree of slackness in the prostitution legislation. It is a categorical variable ranging from 1 to 3 . The classification is made according to the well-known categorization of prostitution policy regimes (Outshoorn 2004), whereby neo-abolitionist countries are grouped together with prohibitionist countries. Countries where buying and/or selling sex is illegal are coded as 1. Countries where it is legal to buy and sell sex but where procuring (e.g. pimping and running a brothel) is illegal are coded as 2. Countries where it is legal to buy and sell sex, pimp or own a brothel are coded as 3. The categorization was based mainly on the 2003 Country Reports on Human Rights Practices from the Bureau of Democracy, Human Rights and Labor. It should be noted that this categorization does not take law enforcement into account, nor the fact that the severity of the punishment differs between countries in the same category. Legal data exist on 46 European countries; in 18 of these prostitution is illegal, in 20 countries prostitution is legal but procuring is illegal, and in eight of the countries both prostitution and procuring are legal. In Table 2 these countries are listed. To take into account the fact that laws are followed to different degrees in different countries and to control for how easy it is to be engaged in organized crime, Jakobsson and Kotsadam (2013) include rule of law (from the World Bank Aggregate Governance Indicators) and heroin smuggling (from UNDOC) as controls.

In line with their hypothesis, the descriptive statistics in Jakobsson and Kotsadam (2013) show that countries with harsher prostitution laws are less subjected to trafficking. In Table 2, each of the 39 European countries in their sample is listed according to the combinations of legal regulation of prostitution and prevalence of trafficking (Trafficking). Among the 13 countries where prostitution is illegal, only one scores High on trafficking prevalence (Bosnia and Herzegovina), and no country in this group scores Very high. In the group of 18 countries where prostitution is legal but procuring is illegal, seven countries score High and two countries score Very high. Where both prostitution and 
Table 2. Prostitution legislation in European countries

\begin{tabular}{lll}
\hline Illegal & Procuring illegal Legal and regulated \\
\hline Albania & Armenia & Austria \\
Andorra & Azerbaijan & Germany \\
Bosnia and Herzegovina & Belgium & Greece \\
Belarus & Bulgaria & Hungary \\
Croatia & Cyprus & Netherlands \\
Liechtenstein & Czech Republic & Switzerland \\
Lithuania & Denmark & Turkey \\
Macedonia & Estonia & \\
Malta & Finland & \\
Moldova & France & \\
Romania & Georgia & \\
Russia & Iceland & \\
Serbia and Montenegro & Ireland & \\
Slovenia & Italy & \\
Sweden & Latvia & \\
Ukraine & Luxembourg & \\
& Monaco & \\
& Norway & \\
& Poland & \\
& Portugal & \\
& Slovakia & Spain \\
& United Kingdom & \\
& and Kotsach & \\
& &
\end{tabular}

Source: Source: Jakobsson and Kotsadam (2010; 2013)

procuring is legal (seven countries) two score High and four score Very high on trafficking prevalence. Although this represents indicative evidence that supports the hypothesis, there may be other factors correlated with both national legislation and trafficking, such as income per capita, population, the rule of law, migration patterns, or organized criminal activity, as described above. Controlling for these other factors that may be of importance for trafficking inflows, the results still hold. In accordance with their theoretical predictions, Jakobsson and Kotsadam find that the trafficking of women for commercial sexual exploitation is least prevalent in countries where prostitution is illegal, most prevalent in countries where prostitution is legalized, and in-between in those countries where prostitution is legal but procuring illegal. However, these results should be regarded with care since the data is problematic in several ways.

As the authors (Jakobsson and Kotsadam, 2013) point out, it should be 
noted that they investigate the quantity of trafficking (as expressed by imperfect data) and not the total welfare consequences of criminalizing the purchase of sex. Harsher prostitution laws may lead not only to decreased quantities of prostitution but also to increased violence and other related acts of criminality, as well as increased stigmatization for women working in these markets. As we discuss in the final section, it may also reduce the number of women working on the streets, which is likely to be more dangerous than working in an apartment. When considering the best legal structure surrounding the market for prostitution and trafficking, all these aspects should be taken into account and more research is needed on them all.

Cho et al. (2013) extend Jakobsson and Kotsadam's (2013) analysis to a worldwide sample of up to 150 countries and similarly find that legalized prostitution increases human trafficking in 116 non-poor countries. Their marginal effects implies that legalized prostitution increases the probability of being in the second highest trafficking category by almost 13 percentage points, and decreases the probability of being in the lowest category by more than five percentage points.

To supplement the quantitative analysis, Jakobsson and Kotsadam (2013) also investigate two cases of legal change and its effect on trafficking (Norway and Sweden). The hypothesis of reduced trafficking from harsher laws is largely supported in these cases. Cho et al. (2013) also conduct case studies of Sweden, Germany and Denmark. Both the cross-country comparisons between Sweden, Denmark and Germany and the temporal comparison within Germany over time and during a legalization of prostitution suggest that trafficking increases as prostitution becomes legalized.

The results relating to where people are trafficked to consistently show that there is more trafficking to countries with slacker prostitution laws. Two more studies confirm this view. Danailova-Trainor and Besler (2006) study what determines trafficking flows. Using country-level estimates of trafficking victim data they find that countries that are more open to globalization and countries with more prostitution are more likely to be destination places for trafficking victims. Another early study which tries to evaluate the effect of national prostitution legislation on trafficking was made by Di Nicola et al. (2005). Examining official victim data from eleven EU countries, they argue that less harsh prostitution legislation may cause more trafficking victims. This conclusion is, however, drawn from a very small sample (11 countries) and from descriptive statistics. 


\section{What factors determine where people are traf- ficked from?}

Another important line of the economics research on trafficking is investigating the mechanisms in the sending countries, which can enlighten the ongoing debate and policy process in the attempts to reduce human trafficking for commercial sexual exploitation. While it has been argued that factors such as poverty, inequality, limited immigration possibilities and the social and economic marginalization of women are likely to play a significant role, until very recently there had not been any research on this issue. The economics papers studying this issue are Della Giusta et al. (2008), Bettio and Nandi (2010), Omar Mahmoud and Trebesch (2010) and Rao and Presenti (2012).

One dataset that has been used is survey data of trafficking victims from Eastern Europe and ex-Soviet states from the International Organization for Migration (IOM), the Counter-Trafficking Module Database. Della Giusta et al. (2008) use this data to study victims of trafficking for sexual exploitation. Of the 5,117 females in the sample, 89 percent were trafficked for sexual exploitation. The countries of origin of these women were Eastern European and ex-Soviet states. Their salary before being trafficked was USD 52 per month; the amount they were being sold for was about USD 4,659 per month. Eighty-four percent were recruited via personal contacts, TV and Internet advertising accounted for 7 percent, 5 percent were kidnapped and 1 percent sold by their family. Also using the IOM data, Bettio and Nandi (2010) investigate which factors influence the violation of basic rights (physical integrity, free movement, access

to medical care, the use of condoms and the exercise of choice over sexual services) among trafficked women. They find that working location and country of work are the main determinants of rights enforcement, while individual and family characteristics play a marginal role.

One of the most common hypotheses in this literature is that trafficking is the result of migration pressures in combination with closed borders (e.g. Omar Mahmoud and Trebesch 2010; Wheaton et al. 2010). A situation where more people want to migrate than is legally possible is said to create a lucrative market for criminal organizations. Once these organizations exist, they diversify into not only people smuggling but also forced trafficking. Omar Mahmoud and Trebesch (2010) develop this line of argument most fully, arguing that two channels should have us predict that trafficking will increase more than propor- 
tionally with larger flows of emigration (on top of the mechanical relationship which stems from the fact that every migrant faces the risk of being trafficked). The first reason is that recruitment costs are lower as it is easier to find potential victims and traffickers can also free ride on other smugglers' facilities (e.g. false documents industries or border-crossing organizations) and reputation. They derive the second reason for the relationship between emigration and trafficking from the economics of immigration literature, stating that higher emigration flows lead to more negative self-selection into migration. Areas with relatively more emigration are often more disadvantaged to start with and people from those areas are likely to be more desperate and take more risks. In addition, a common argument is that more emigration from an area reduces the marginal cost of migration and hence poorer and less educated migrants will be able to migrate (e.g. McKenzie and Rapoport 2010). It is argued that the negative self-selection makes it easier for traffickers to deceive people (Wheaton et al. 2010).

The migration pressures in turn are the result of absolute and relative poverty. When people are very poor they become desperate and when there are large regional inequalities the potential gains from migration are higher. As Omar Mahmoud and Trebesch (2010) argue, the two channels of lower recruitment costs and negative self-selection may also be mutually reinforcing: the negative self-selection may have feedback effects on network quality so that the network of migrants are worse at protecting themselves. Omar Mahmoud and Trebesch (2010) empirically investigate the determinants of where people are trafficked from. They do not only investigate trafficking for sexual purposes, but all types of trafficking. The definition of trafficking in the paper is a situation where the individual was coerced and forced to work for little or no reward.

Omar Mahmoud and Trebesch (2010) use two datasets. The first dataset consists of household surveys from five Eastern European countries (Belarus, Bulgaria, Moldova, Romania and Ukraine) and 5,513 households from 82 regions. These data were collected by the International Organization for Migration (IOM) in 2006 (see IOM 2006). In total, 1,563 of these households had a migrant family member and 7 percent of these (108 households) reported having had a trafficked household member. Out of these, 22 reported that the type of trafficking was to the sex industry. As trafficking for sexual exploitation is highly stigmatized, Omar Mahmoud and Trebesch (2010) argue that the data probably suffers from reporting bias. The second dataset comes from Moldova, 
the Eastern European country which is most affected by human trafficking, and includes 1,679 migrants from 211 localities.

In line with their theoretical predictions Omar Mahmoud and Trebesch (2010) find more reported trafficking in areas with larger emigration, and they argue that the reasons for this are likely to be a combination of lower recruitment costs and more negative self-selection. They find migration prevalence to be a predictor of human trafficking. A one-percentage point increase in the share of migrant households in a region is associated with a 0.056 percentage point higher likelihood of having a trafficked family member (or a 5 percent increase in the predicted probability). With respect to regional poverty, rurality or infant mortality, they find no indications of such factors being important for the incidence of trafficking once migration prevalence is controlled for. Nor do they find any correlation between criminal activity in the region and trafficking.

Rao and Presenti (2012) use the UNDOC data presented above (which was used by Jakobsson and Kotsadam (2013), and Cho et al. (2013) to study receiving countries) to study the relationship between two main variables (GDP per capita and gender inequality) and the outflow of trafficking from a country. The sample is global and includes 118 countries. Interestingly, this paper links trafficking to migration by testing two hypotheses that originate in the economic immigration literature. They investigate how gender equality and poverty are related to trafficking and they connect their findings with findings from the more general migration literature.

The relationship between gender inequality and trafficking is often assumed to be positive, with increased gender inequality unambiguously leading to more trafficking. As Rao and Presenti (2012) argue, two different mechanisms are likely to be at play in such a relationship. First, if trafficking victims are a subset of female economic migrants, incomes in the country of origin and possible incomes abroad are generally compared and are a function of gender equality. Second, women in countries with less gender equality are likely to be valued less, which increases their general vulnerability and the likelihood of their being sold to traffickers. They measure gender inequality with four variables: women's literacy, sex ratios, the female-male income ratio, and the female-male life expectancy ratio.

The relationship between poverty and trafficking is also generally assumed to be positive, with poor women deciding to migrate illegally and thereby at greater risk of being trafficked. Rao and Presenti (2012) nicely connect this to the immigration literature and thereby reach a more nuanced hypothesis. In the 
migration literature, the relationship between poverty and migration is assumed (and often found to be) negative. The reasons are the costs of migration, which work to deter the poorest segments of the population. Furthermore, the richest have little incentive to migrate, leaving middle-income people as the most likely migrants. Indeed, their countries of origin and migration data show an inverse U-shaped relationship between migration and income. They conclude this may be true for trafficking as well. Income is measured as GDP per capita, but they also include a headcount ratio of poverty.

In testing these two hypotheses they control for being a transition economy, population, landlockededness, conflicts and rule of law. The main result is that women's literacy and low sex ratios had no statistically significant relationship to trafficking. However, the female-male income ratio was positively and statistically significantly related to trafficking incidence. The female-male life expectancy ratio was also positively and statistically significantly related to trafficking origin, but not in all specifications. That is, trafficking is not more likely in countries with greater gender inequality. With respect to income and poverty they find that it is not the poorest countries of the world that have the most trafficking. Similarly to the general literature on migration they find that the relationship between GDP per capita and trafficking has an inverted U-shape. That is, both the richest and the poorest countries were less likely to appear as sending countries in the reports in the UN trafficking database. Rao and Presenti (2012) argue that these results indicate that it is in societies permissive enough to allow women to travel alone and be potential economic migrants that trafficking has the most potential to originate.

\section{Papers that integrate sending and receiving coun- tries}

There are a few economics papers that work toward integrating the analysis of trafficking to include both sending and receiving countries (Wheaton et al. 2010; Akee et al. 2011; Cho 2012). Akee et al. (2011) presents a two-way bargaining model where trafficking arises as a consequence of a middleman's response to buyers' willingness to pay for sex in host and destination countries. Victim protection programs and law enforcement against prostitution affect the probability of discovery and work stoppage. The implications of the model depend crucially on the elasticity of buyer demand: if demand is inelastic an 
increase in the risk of discovery in the destination country will raise the buyers' willingness to pay in that country and increase the inflow of trafficking. An increase in the risk of discovery in the source country will increase buyers' willingness to pay there and thus discourage the outflow of trafficking. As argued by Cho et al. (2013), the above model does not tell us very much about the effect of the legalization of prostitution since it is implicitly assumed that the legalization of prostitution is equal to laxer enforcement of anti-trafficking laws. And, by equating the legal status of prostitution with different degrees of law enforcement with respect to human trafficking, they do not account for other demand and supply effects that prostitution legislation may have on trafficking.

Akee et al. (2011) use data from the Trafficking in Persons Report (US Department of State 2003), and the Protection Project Country Report (2002) to construct two sets of information of each country: (i) if the country is receiving international trafficking, sending victims, if it is both sending and receiving, or if it does neither, and (ii) they identify the trafficking links between countries. From this information they constructed a binary variable for all potential sending and receiving pairs of countries. Information about the legal framework is taken from the Protection Project Country Report (2002).

Of the 187 countries in their dataset, 42 countries are sending countries, 45 are receiving countries, 66 are both senders and receivers, while 44 countries have no reports of trafficking (or less than 100 cases). Using this data they estimate a gravity model to examine the trafficking flows. The dependent variable is a binary variable indicating if there are any reported cases of trafficking from each possible pair of countries. Independent variables are if receiving countries grants legal amnesty to trafficking victims and if prostitution is banned (they do not provide any information on the coding of the legal variable, or which countries that are included in the different categories), and there are a number of control variables commonly included in empirical migration models (e.g. GDP in both countries, distance between the countries, common border, region, and political conditions). Their probit estimations show a positive relationship between granting amnesty for trafficking victims and being a receiving country (the marginal effect varies from 0.8 to 5.7 percentage points depending on which other factors are controlled for in the estimations). They find a statistically insignificant and very small relationship between being a receiving country and banning prostitution (marginal effects varies from 0 to 0.2 percentage points); the marginal effects for being a sending country are very small (marginal effects varies from 0.1 to 0.5 percentage points) and statistically insignificant. 
Recognizing that there may be endogeneity problems regarding trafficking flows and giving amnesty to trafficking victims - it may, for example, be the case that countries with many trafficking victims implement such laws - they propose an instrumental variable approach to control for this. Using legal origin and settler mortality as instruments that they argue affect the likelihood of implementing amnesty laws but not affecting trafficking flows when controlling for observed factors, they still find a positive ship between being a receiver of trafficking and granting amnesty to trafficking victims. For some of the specifications the relationship between prostitution bans and trafficking becomes statistically significant, but still with very small marginal effects, and the reason that the prostitution legislation effect becomes statistically significant is possibly due to the change in the sample resulting from the inclusion of settler mortality as an instrument. Furthermore, as Cho et al. (2013) points out, prostitution legislation is still regarded as exogenous. More problematic, in our view, is the exclusion restriction of the instrument. While settler mortality affected settlements it is not clear what the settlers might have brought with them. The instrument was first used by Acemoglu et al. (2001) to control for the endogeneity of institutions and was later forcefully criticized by Glaeser et al. (2004), since the settlers may have brought other things, such as human capital, guns, germs and steel. With respect to a specific law, as the instrument is used here, it is even less likely that the exclusion restriction holds. Nonetheless, we think it is a good first attempt to deal with some of the endogeneity issues in this line of research.

In a theoretical contribution, Wheaton et al. (2010) present an economic model of human trafficking encompassing trafficking for sexual and other purposes. In their model they consider three types of agents in the trafficking market, namely vulnerable populations making up the pool of potential migrants, employers with demand for cheap, yet diversified labor, and traffickers as intermediaries. The market is argued to be one characterized by monopolistic competition with many traffickers and employers, but with differentiated products. That is, the trafficked victims are assumed to differ on essential attributes and the trafficked persons can be used for different purposes. To increase the costs of employers using trafficked labor and to increase the costs for traffickers (whether through direct costs or increasing the probability of going to prison) and to lower the need to relocate and the vulnerability of those who do relocate is argued to be ways to decrease trafficking in general. The empirical questions are left for future studies as data becomes available. 
In a recent contribution, Cho (2012) conducts a comprehensive empirical analysis of both sending and destination countries for human trafficking. Conducting an extreme bounds analysis, running more than two million regressions, she tests the robustness of 145 variables. She uses three datasets with information on trafficking: the UNODC index covering 161 countries and aggregated numbers over the period 1996-2003; the United States Department of State (2001-2011) which categorizes countries into major destinations/origins based on the classification of whether a country experiences more than 100 reported cases of in/outflows in a given year and includes 190 countries; the International Labor Organization (ILO) data described above (and used by Jakobsson and Kotsadam, 2013) which provides the aggregate number of trafficking cases during the 1995-2000 period, covering a maximum of 74 countries.

Cho (2012) finds that crime prevalence is an important factor both for sending and destination countries when controlling for migration. She investigates 70 push and 63 pull factors suggested in the trafficking literature in a sample of up to 180 countries. Contrary to previous literature, she does not find migration to be a consistent predictor of trafficking. Cho (2012) also finds that gender discrimination and low development indicators of the vulnerability of people to trafficking do not demonstrate robust effects, while some gender-related indicators such as high fertility rates have constraining effects that are contrary to expectations. As the majority of victims are female one would expect gender discrimination to be of importance. Cho (2012) finds no robust relationship between any of the gender-related indicators (female literacy, years of schooling, labor-force participation, or economic, social and political rights) and inflow or outflow of trafficking. This average relationship may mask substantial heterogeneity and nonlinearities, however. As Cho (2012) herself point out, women need to have sufficient autonomy to migrate in the first place.

With respect to prostitution laws, Cho (2012) finds them related to trafficking inflows, but the relation is not statistically significant in the global sample: only for a sample of richer countries is the finding statistically significant. This is well in line with the work of Jakobsson and Kotsadam (2010, 2013), who find the same relationship for 37 European countries. Whether this is due to rule of law, different enforceability of prostitution laws or income in itself is not clear.

\section{Discussion}

In this chapter we have presented the recent contributions of economists 
to the questions of what factors determine where people are trafficked to and what factors determine where they are trafficked from. We have argued that economists should have a lot to say about the market for sexual slavery since it is guided by profit motives and because there is an extensive existing pool of economics literature on immigration and crime. We argue that the economic literature on human smuggling (see Friebel and Guriev 2012 for an overview) is particularly promising and should to a greater extent than at present be incorporated by economists studying trafficking. Of the studies reviewed in this chapter, we find Wheaton et al. (2010), Omar Mahmoud and Trebesch (2010) and Rao and Presenti (2012) to be the most advanced in linking the problem of trafficking to these other strands of the economics literature.

Economists have mainly been occupied with the question of where people are trafficked to, and one area of particularly high research activity has been on the relationship between national prostitution laws and the prevalence of trafficking (Jakobsson and Kotsadam 2010, 2013; Cho 2012; Cho et al. 2012; Akee et al. 2011; Danailova-Trainor and Belser 2006; Di Nicola et al. 2005). These studies are based on rational choice frameworks but they differ somewhat in their predictions. Jakobsson and Kotsadam (2010; 2013) argue that laws against prostitution make trafficking to a country more costly and they therefore predict that the amount of trafficking to that country should be lower in such cases. Cho (2012) and Cho et al. (2013) importantly add to this framework the theoretical possibility that it is a priori equally likely that the composition of the prostitutes may shift towards fewer nationals or fewer foreign nationals with working permits once laws against prostitution are put in place and that trafficking may therefore increase. A similar argument in made in Akee et al. (2011), where the implications of the model furthermore depend on the elasticity of buyer demand. They do not distinguish between laws regarding buying or selling sex, and in fact it is not clear how the law variable is coded; we have argued elsewhere (Kotsadam and Jakobsson 2011) that criminalizing buying sex may affect the demand for buying sex, both via the risk of legal punishment but also via a normative channel whereby lawmakers signal what are the socially acceptable norms regarding the buying and selling of sex.

There are not only differences in the theoretical predictions but the empirical results also differ somewhat in the different studies. Jakobsson and Kotsadam (2010; 2013) found trafficking to be positively correlated with the slackness of the prostitution laws for a sample consisting of European countries; also when controlling for possible confounding variables. Cho et al. (2013) extend the 
analysis to a worldwide sample and find similar results. On the other hand, Cho (2012) does not find prostitution law to be a robust predictor in her recent working paper in a global sample of 180 countries. Limiting the sample to richer countries, however, the results are in line with the findings in Jakobsson and Kotsadam (2013). Akee et al. (2011) also investigate the relationship between prostitution laws and the inflow of trafficking in a global sample and find no robust relationship. As they do not distinguish between rich and poor countries we do not know whether this lack of relationship masks an important heterogeneity or not. Furthermore, even if there is a consistent difference between rich and poor countries we still do not know which mechanisms drive such a result. It could be income per se, or it could be other factors such as rule of law, geography or law following norms. One aspect highlighted in Lee and Persson (2012) is the female-male income ratio since voluntary prostitution decreases with the gender wage gap in their model. Rao and Presenti (2012) also found this ratio to be important for sending countries. This is a clear hypothesis that can easily be tested and future research should in general investigate this potential heterogeneity closer.

While several of the studies mentioned above complement their cross-country regression results with case studies (Jakobsson and Kotsadam 2013; Cho et al. 2012), these case studies have merely been descriptive and we therefore still lack studies identifying causal effects of prostitution laws on trafficking flows. This line of research should be a priority, we argue, as there are many examples of legal changes in the prostitution field and since the question is actively debated in policy circles. Unfortunately, data limitations have so far limited this possibility and if questions regarding trafficking are not included in more surveys it is likely to continue to be under-researched. Scholars interested in trafficking should therefore either collect their own data or lobby for the inclusion of trafficking-related questions in other surveys. More panel data on trafficking incidence would make it possible to draw much more robust conclusions on the relationship between legal framework and trafficking prevalence. The question of spillover across countries is also intriguing and is yet to be investigated. One hypothesis that could be tested is whether laws against prostitution in one country makes trafficking more likely in neighboring countries or in other countries in general.

With respect to what factors determine where people are trafficked from there is actually some micro data on trafficking from the International Organization for Migration. Omar Mahmoud and Trebesch (2010) used an early 
version of this data to test several hypotheses about where people are trafficked from. Their main findings are that there is more trafficking from areas with larger emigration. They find no correlation between regional poverty, degree of urbanization or infant mortality and trafficking from Eastern Europe. Nor do they find any correlation between criminal activity in the region and trafficking. This is in contrast to Cho (2012), who finds that crime prevalence is correlated with both sending and receiving countries in a global sample. Furthermore, Cho (2012) does not find a direct effect of migration but suggests that migration may have indirect linkage with human trafficking via globalization (some globalization indicators turn out to have significant, positive impact on human trafficking).

We believe that the recent contributions by Cho (2012) and Rao and Presenti (2012) are important and advance the literature in several ways. The study by Cho (2012) answers some questions but poses several more. For instance, why is it that she finds a positive relationship between gender equality and trafficking, and between development and trafficking? As Rao and Presenti (2012) argue, barriers to mobility in the most gender-unequal countries are likely to contribute to their relatively low prevalence of trafficking by lowering the propensity of women to migrate alone. In general, some interactions between the different factors would be of interest, and investigations of non-linearities as well. As Cho (2012) herself writes, her results that many of the proposed mechanisms from previous literature are not robust does not necessarily imply that they are not important for determining trafficking incidence. There may for instance be indirect links and interactive effects of some of the variables. We are confident that more analyses with this data will lead to further understanding of the relationship between factors such as poverty, emigration and gender equality on the one hand and trafficking on the other.

We think the literature on the determinants of where people are trafficked from has some low-hanging fruits in terms of research possibilities. One immediate study could be to take advantage of the now wider dataset from the International Organization for Migration. The IOM Counter-Trafficking Module (2010) now has a sample size of about 25,000 victims from 130 countries covering 10,000 victims, according to Cho (2012), and we have yet not seen any analysis of this material. The emigration hypotheses could be more credibly tested with such data, exploiting, for example, the expansion of the European Union. The prediction would be that as legal emigration becomes a more readable option, the demand for illegal emigration and its supposedly other criminal 
elements would be reduced and hence trafficking as well. Another hypothesis could be that trafficking increases simply because more people start moving. Furthermore, this data contains information about where people are trafficked to so it could also be used to investigate the relationship between prostitution laws and trafficking discussed above. In addition, the dataset could be used to extend the analysis by Bettio and Nandi (2010), who investigate which factors influence the violation of basic rights (physical integrity, free movement, access to medical care, the use of condoms and the exercise of choice over sexual services) among trafficked women. One hypothesis could be that criminalization of prostitution makes the market go underground and that people still selling sex under such a regime would become more vulnerable. Another hypothesis could be that as street prostitution declines, the work environments for sex sellers improve when prostitution is illegal. Assessing such factors would be important in order to evaluate the total welfare effects of different legal responses to prostitution. Eyeballing the data in Bettio and Nandi (2010) we find no indications of more or less vulnerability in different legal contexts, but more systematic research could be conducted in this field. The theoretical contribution by Lee and Persson (2012) is also relevant in this respect as they try to find a policy that both protects the voluntary prostitutes and limits trafficking. Their preferred legal solution is to have regulated and monitored prostitution combined with severe punishments for people buying sex outside the regulatory domain. The voluntary prostitutes would prefer to work in safe and regulated brothels as prices there would be higher (those in illegal brothels must compensate the men for the risk of getting caught) and severe penalties for buying sex outside the regulated brothels would lower demand for trafficked women.

With respect to sending countries there are many policies that could and should be investigated. If economic distress and vulnerability are important factors for trafficking outflow, then insurance programs and employment programs could be important factors limiting trafficking. This again probably requires that researchers in this field start collecting their own data. Omar Mahmoud and Trebesch (2010) also find that trafficking is lower from regions where knowledge about trafficking is higher. Hence information campaigns may be important for limiting trafficking. As these results follow from mere correlations it is difficult to draw clear policy conclusions, but they points to an important area for future research. In particular, information campaigns could be randomized and exogenous variation in migration could possibly be exploited. In general, there is no single study in the trafficking field that has teamed up with any of the 
many organizations working to prevent trafficking to test out what works and what does not work to limit the extent of people being trafficked from a place. Finally, the issue of domestic trafficking is an area that merits both theoretical and empirical work as it is not certain that the same push and pull factors determine domestic and international trafficking. 


\section{References}

[1] D. Acemoglu, S. Johnson, and J. Robinson, "The Colonial Origins of Comparative Development: An Empirical Investigation", American Economic Review, vol. 91, no. 5, pp. 772-793, 2001.

[2] E. Aghatise, "Trafficking for Prostitution in Italy: Possible Effects of Government Proposals for Legalization of Brothels", Violence Against Women, vol. 10, no. 10, pp. 1126-1155, 2004.

[3] F. Bettio and T.K. Nandi, "Evidence on Women Trafficked for Sexual Exploitation: A Rights-Based Analysis", European Journal of Law and Economics, vol. 29, no. 1, pp. 15-42, 2010.

[4] S-Y. Cho, A. Dreher, and E. Neumayer, "Does Legalized Prostitution Increase Human Trafficking?", World Development, vol. 41, pp. 67-82, 2013.

[5] M. Della Giusta, "Simulating the Impact of Regulation Changes on the Market for Prostitution Services", European Journal of Law and Economics, vol. 29, no. 1, pp. 1-14, 2010.

[6] E. Glaeser, L. La Porta, F. Lopez-de-Silanes, and A. Schleifer, "Do Institutions Cause Growth?", Journal of Economic Growth, vol. 9, no. 3, pp. 271-303, 2004.

[7] N. Jakobsson and A. Kotsadam, "Gender Equity and Prostitution: An Investigation of Attitudes in Norway and Sweden", Feminist Economics, vol. 17, no. 1, pp. 31-58, 2011.

[8] N. Jakobsson and A. Kotsadam, "The Law and Economics of International Sex Slavery: Prostitution Laws and Trafficking for Sexual Exploitation", European Journal of Law and Economics, vol. 35, no. 1, pp. 87-107, 2013.

[9] N. Jakobsson and A. Kotsadam, "Shame on you John! Laws, Stigmatization, and the Demand for Sex", European Journal of Law and Economics, vol. 37, no. 3, pp. 393-404, 2014.

[10] K. Kangaspunta, "Mapping the Inhuman Trade: Preliminary Findings of the Database on Trafficking in Human Beings", Forum on Crime and Society, vol. 3, no. 1-2, pp. 81-103, 2003.

[11] A. Kotsadam and N. Jakobsson, "Do Laws Affect Attitudes? An Assessment of the Norwegian Prostitution Law using Longitudinal Data", International Review of Law and Economics, vol. 31, no. 2, pp. 103-115, 2011.

[12] D. McKenzie and H. Rapoport, "Self Selection Patterns in Mexico-U.S. Migration: The Role of Migration Networks", Review of Economics and Statistics, vol. 92, no. 4, pp. 811-821, 2010. 
[13] T. Omar Mahmoud and C. Trebesch, "The Economics of Human Trafficking and Labour Migration: Micro-evidence from Eastern Europe", Journal of Comparative Economics, vol. 38, no. 2, pp. 173-188, 2010.

[14] S. Rao and C. Presenti, "Understanding Human Trafficking Origin: A Cross-Country Empirical Analysis", Feminist Economics, vol. 18, no. 2, pp. 231-263, 2012.

[15] J. Salt, "Trafficking and Human Smuggling: A European Perspective", International Migration, vol. 38, no. 3, pp. 31-56, 2000.

[16] J. Salt and J. Stein, "Migration as a Business: The Case of Trafficking", International Migration, vol. 35, no. 4, pp. 467-489, 1997.

[17] E. M. Wheaton, E. J. Schauer, and T. V. Galli, "Economics of Human Trafficking", International Migration, vol. 48, no. 4, pp. 114-141, 2010.

[18] R. Akee, A. Bedi, Ak. Basu, and N. H. Chau, "Transnational Trafficking, Law Enforcement and Victim Protection: A Middleman Trafficker's Perspective", IZA DP No. 6226, 2011.

[19] S-Y. Cho, "Modeling for Determinants of Human Trafficking?", Economics of Security Working Paper No. 70, Berlin, 2012.

[20] G. Danailova-Trainor and P. Belser, "Globalization and the Illicit Market for Human Trafficking: An Empirical Analysis of Supply and Demand", International Labour Office, Working Paper 53, 2006.

[21] N. Jakobsson and A. Kotsadam, "The Law and Economics of International Sex Slavery: Prostitution Laws and Trafficking for Sexual Exploitation", Scandinavian Working Papers in Economics, No. 458, 2010.

[22] S. Lee and P. Persson, "Human Trafficking and Regulating Prostitution", NYU Law and Economics Research Paper Series, Working Paper No. 12-08, 2012.

[23] J. Morrison and B. Crosland, "The Trafficking and Smuggling of Refugees - The End Game in European Asylum Policy?", Working Paper No. 39, UNHCR, New Issues in Refugee Research, 2001.

[24] G. Friebel and S. M. Guriev, "Human Smuggling", IZA Discussion Paper No. 6350, 2012.

[25] B. Anderson and J. O'Connell Davidson, "Trafficking: A Demand Led Problem? A Multi-country Pilot Study", 2002.

[26] A. Di Nicola, I. Orfano, A. Caudro, and N. Conci, "Study on National Legislation on Prostitution and the Trafficking in Women and Children", 2005 . 
[27] European Commission, "EU Action against Trafficking in Human Beings", 2009.

[28] UNODC, "Trafficking in Persons: Global Patterns", 2006.

[29] UNODC, "Global Report on Trafficking in Persons", 2009.

[30] US Department of State, "The Link Between Prostitution and Sex Trafficking", 2004.

[31] US Department of State, "Trafficking in Persons Report", 2001-2011.

[32] M. Della Giusta, M. L. Di Tommaso, and S. Strøm, Sex Markets: A Denied Industry, Routledge, London and New York, 2008.

[33] J. Outshoorn, "Introduction: Prostitution, Women's Movements and Democratic Politics", in The Politics of Prostitution - Women's Movements, Democratic States and the Globalisation of Sex Commerce, J. Outshoorn, Ed. Cambridge University Press, Cambridge, 2004.

[34] Ot.prp. nr. 48, "Om lov om endring i straffeloven 1902 og straffeprosessloven (kriminalisering av kjøp av seksuell omgang eller handling mv.)", 2007.

[35] Proposition, "Kvinnofrid", 1997/1998:55. 


\section{Appendix}

Table A1. An overview of the trafficking data used in the papers discussed in this chapter

\begin{tabular}{|c|c|c|c|c|}
\hline Data & $\begin{array}{l}\text { Description, } \\
\text { unit of } \\
\text { observation }\end{array}$ & \begin{tabular}{|l|} 
Trafficking \\
measures
\end{tabular} & Type of data & $\begin{array}{l}\text { Publications using } \\
\text { the data }\end{array}$ \\
\hline $\begin{array}{l}\text { Report on } \\
\text { Trafficking in } \\
\text { Persons: Global } \\
\text { Patterns } \\
\text { (UNDOC 2006) }\end{array}$ & 161 countries & $\begin{array}{l}\text { Incidence of } \\
\text { reporting of } \\
\text { source, transit, } \\
\text { and destination } \\
\text { countries on a six } \\
\text { point scale ranging } \\
\text { from no trafficking } \\
\text { to very high }\end{array}$ & $\begin{array}{l}\text { Based on a content } \\
\text { analysis of } \\
\text { information from } 113 \\
\text { institutions providing } \\
\text { human trafficking } \\
\text { information }\end{array}$ & \begin{tabular}{|l|}
$J a k o b s s o n$ and \\
Kotsadam \\
(forthcoming), Cho \\
(2012) Cho et al. \\
(forthcoming), Rao \\
and Presenti (2012)
\end{tabular} \\
\hline $\begin{array}{l}\text { International } \\
\text { Labour } \\
\text { Organization }\end{array}$ & 74 countries & $\begin{array}{l}\text { Number of } \\
\text { trafficking cases in } \\
\text { a country }\end{array}$ & $\begin{array}{l}\text { The average of the } \\
\text { available estimates } \\
\text { for each country in } \\
\text { the ILO database. } \\
\text { The data was } \\
\text { constructed by } \\
\text { Danailova-Trainor } \\
\text { and Belser (2006) }\end{array}$ & $\begin{array}{l}\text { Danailova-Trainor } \\
\text { and Belser (2006), } \\
\text { Jakobsson and } \\
\text { Kotsadam } \\
\text { (forthcoming), Cho } \\
\text { (2012), Cho et al. } \\
\text { (forthcoming) }\end{array}$ \\
\hline $\begin{array}{l}\text { US Department } \\
\text { of State } \\
\text { Trafficking in } \\
\text { Persons Report } \\
\text { (2001-2011) }\end{array}$ & 190 countries & $\begin{array}{l}\text { Destination and } \\
\text { origin countries if } \\
\text { more than } 100 \\
\text { cases of trafficking } \\
\text { is reported each } \\
\text { year }\end{array}$ & $\begin{array}{l}\text { Data is based on } \\
\text { reports in the host } \\
\text { countries where at } \\
\text { least } 100 \text { cases } \\
\text { Of trafficking have } \\
\text { been discovered for } \\
\text { the last year. }\end{array}$ & $\begin{array}{l}\text { Cho (2012) and } \\
\text { Akee et al. (2011) }\end{array}$ \\
\hline $\begin{array}{l}\text { Counter- } \\
\text { Trafficking } \\
\text { Module } \\
\text { Database (IOM } \\
\text { 2006) }\end{array}$ & $\begin{array}{l}\text { 5,117 females } \\
\text { from Eastern } \\
\text { Europe }\end{array}$ & $\begin{array}{l}\text { Country of origin, } \\
\text { salary before } \\
\text { trafficking, sales } \\
\text { price, mechanism } \\
\text { of enslavement }\end{array}$ & Household survey & $\begin{array}{l}\text { Della Giusta et al. } \\
\text { (2008), Bettio and } \\
\text { Nandi (2010), } \\
\text { Mahmoud and } \\
\text { Trebesch (2010) }\end{array}$ \\
\hline $\begin{array}{l}\text { Moldova study } \\
\text { (Mahmoud and } \\
\text { Trebesch 2010) }\end{array}$ & $\begin{array}{l}1,679 \text { men } \\
\text { and women } \\
\text { from } 211 \\
\text { localities in } \\
\text { Moldova }\end{array}$ & \begin{tabular}{|l|} 
Similar to IOM \\
(2006) but more \\
detailed data
\end{tabular} & $\begin{array}{l}\text { Household survey } \\
\text { combined with local } \\
\text { administrative data }\end{array}$ & $\begin{array}{l}\text { Mahmoud and } \\
\text { Trebesch (2010) }\end{array}$ \\
\hline
\end{tabular}

